\title{
Laboratory study of the life cycle of a freshwater strombidiid ciliate
}

\author{
Helga Müller* \\ Private Laboratory, Jacob-Burckhardt-Str. 18, 78464 Konstanz, Germany
}

\begin{abstract}
Sediment samples containing resting cysts of the planktonic ciliate Pelagostrombidium sp. were collected in October/November 2000 in Lake Mondsee, Austria, with sediment traps and stored at ca. $4^{\circ} \mathrm{C}$ in the dark. Within $6 \mathrm{mo}$, concentrations of viable cysts in these samples decreased to less than $4 \%$ of initial numbers, probably due to the combined effects of predation, infection and excystment. Spontaneous excystment at low temperatures was first observed in March 2001, when the cysts were ca. 4 mo old. Excystment of 2 to 5 mo old cysts could be triggered by a temperature shift from ca. 4 to $18^{\circ} \mathrm{C}$ in the presence of food algae. White light slightly enhanced this response. From excysted individuals, 12 non-clonal strains were established and maintained with cryptomonads as food. All strains produced cysts, which were first observed ca. 3 wk after excystment. Experiments with these laboratory cysts revealed that excystment could be triggered by a temperature stimulus in cysts older than 1 mo and occurred spontaneously at low temperatures in cysts older than 3 mo. The results of the present study suggest that cyst age and temperature are the main factors controlling excystment of Pelagostrombidium sp., and that the period of dormancy of this ciliate in sediments of temperate lakes generally does not exceed 6 mo. Cysts produced at the end of the growing season will excyst in early spring, whereas cysts formed in spring are likely to excyst in summer.
\end{abstract}

KEY WORDS: Oligotrich ciliates $\cdot$ Strombidiid ciliates $\cdot$ Pelagostrombidium $\cdot$ Resting stage $\cdot$ Dormancy $\cdot$ Excystment $\cdot$ Encystment

Resale or republication not permitted without written consent of the publisher

\section{INTRODUCTION}

Cyst formation is a common event in the life cycle of several groups of free-living protozoa. In their broad review of the subject, Corliss \& Esser (1974) point especially to the different types and functions of protozoan cysts and to the large variety of factors which may induce encystment. In more recent years, the cell differentiation process during ciliate encystment has been studied in great detail (for reviews see Gutiérrez et al. 1998, 2001). The majority of these studies were performed with colpodid and hypotrich ciliates, which form resting cysts as a response to starvation and/or desiccation.

Among oligotrich ciliates, several planktonic species are known to form resting cysts. However, the role of

*E-mail: helga.mueller.konstanz@t-online.de these cysts in the life cycle and the factors which trigger encystment are as yet only poorly understood (for a review see Müller 2000). Excystment within this group has been studied only in marine species (e.g. Paranjape 1980, Kamiyama \& Aizawa 1990, Kim \& Taniguchi 1995, 1997). A species from a different habitat, namely Strombidium oculatum living in tide pools, is well known for its circatidal rhythm of en- and excystment. The short-lived cysts (ca. 19 h) of this oligotrich ciliate serve to retain the population in its pool during flooding by the high tide (Fauré-Fremiet 1948, Jonsson 1994, Montagnes et al. 2002).

The present investigation deals with an oligotrich ciliate of the genus Pelagostrombidium, a taxon which is common in the plankton of freshwater lakes (Foissner et al. 1999). Species identification was not attempted, since the taxonomic separation of the 2 species within this genus, $P$. fallax and $P$. mirabile, is presently unsettled, as discussed in detail by Müller et 
al. (2002, this issue). Most probably, the species investigated here is identical with the species studied by Müller (1996) and Müller \& Wünsch (1999) in Lake Constance, Germany.

For the first time, a complete polymorphic cycle of a freshwater oligotrich ciliate was studied in the laboratory. It comprised excystment from sediment samples, vegetative growth and cyst formation in culture, dormancy, and excystment of the laboratory cysts. These observations were combined with data from previous field studies (Müller \& Wünsch 1999, Müller et al. 2002) to give a tentative description of the life cycle of Pelagostrombidium sp. in its natural environment.

\section{MATERIALS AND METHODS}

Sediment samples. The starting material for the present investigation were 3 samples which had been collected with sediment traps in Lake Mondsee, Austria, during a field study (Müller et al. 2002). These sediment samples (numbers 51 to 53 of the field series) were collected during trap exposures from October 25 to 31 , October 31 to November 7 , and November 7 to 15, 2000, and contained large numbers of Pelagostrombidium cysts. Immediately after trap retrieval, the samples were sieved through $200 \mu \mathrm{m}$ mesh and the fractions $<200 \mu \mathrm{m}$ were stored at ca. $4{ }^{\circ} \mathrm{C}$ in the dark (i.e. 'cold/dark conditions'). They were diluted with cold sterile filtered lake water 4 to 12 d later to obtain $100 \mathrm{ml}$ samples with cyst concentrations of ca. 75 cysts $\mathrm{ml}^{-1}$. These samples and, later on, the cultures established from emerging ciliates were studied from January through August 2001.

Determination of cyst concentrations. Live Pelagostrombidium cysts in sediment samples are almost impossible to detect, since they are masked by detritus particles adhering to their spiny surface. For enumeration of cysts, therefore, $3.5 \mathrm{ml}$ subsamples were taken after thorough mixing and fixed with acid Lugol's solution. These were filled into Sedgewick-Rafter chambers and 3 entire chambers $(3 \mathrm{ml})$ were scanned for strombidiid cysts. Three different categories of cysts were recorded separately: (1) 'intact cysts', which had an intact plug and cell content, the latter being darkly stained with acid Lugol's solution; (2) 'defect cysts', which had partly or totally lost their cell content and thus appeared light brown or colorless, although the cyst wall and plug seemed to be undamaged; and (3) 'open cysts', without plug and cell content, obviously the remnants of excystment.

Excystment experiments with sediment samples (Expts 1 to 5). These experiments were performed in 24 well tissue culture plates (Costar). A suspension of Cryptomonas sp. (Strain 26.80 from the culture collec- tion in Göttingen, Germany) in $1.2 \mathrm{ml}$ of sterile filtered lake water was added to each well at concentrations of approximately $3 \times 10^{4}$ cells ml ${ }^{-1}$. Subsequently, defined volumes of live sediment samples were filled into the wells. Cyst concentrations were determined prior to each experiment in Lugol-fixed subsamples, as described above.

Expt 1 was started on 7 January 2001 with Sediment Samples 51, 52 and 53. From each sample, $60 \mu \mathrm{l}$ were inoculated into each well of 1 plate; an additional control plate received only Cryptomonas. The plates were incubated at 16 to $18^{\circ} \mathrm{C}$ and illuminated with a white fluorescent light tube on a 12:12 h light:dark cycle at an irradiance of $15 \mu \mathrm{mol}$ photons $\mathrm{m}^{-2} \mathrm{~s}^{-1}$ (i.e. 'warm/ light conditions'). Over $5 \mathrm{~d}$, all wells were checked daily for emerging ciliates and other aquatic organisms under a dissecting microscope at 50-fold magnification.

Expts 2, 3, 4 \& 5 were started on January 15, February 18, March 31 and April 15, respectively, using only Sediment Sample 51. The size of the inoculate (30 to $180 \mu \mathrm{l})$ was adjusted to the actual cyst concentration, such that in each experiment approximately 2 intact cysts were added to each well. Three parallel plates were prepared, which were incubated under cold/dark conditions, at warm/light conditions and at 16 to $18^{\circ} \mathrm{C}$ in the dark (i.e. 'warm/dark conditions'). As in Expt 1, all wells were checked for excysted organisms over 5 to $7 \mathrm{~d}$.

Start and maintenance of ciliate cultures. Strombidiid ciliates emerging in the experimental plates were identified to the genus Pelagostrombidium by observation in vivo. Individuals which had multiplied in the plates of Expts 1, 3, 4 \& 5 were used to start nonclonal cultures. A total of 12 strains (including 3 pairs of parallel strains derived from the same experimental well) were maintained for 1 to $4 \mathrm{mo}$ at ca. $12^{\circ} \mathrm{C}$ on a 12:12 h light/dark cycle in glass dishes containing $50 \mathrm{ml}$ of sterile filtered lake water with food (Cryptomonas Strain 26.80) in excess. Bacteria and heterotrophic nanoflagellates were also present in these cultures.

Harvest of cysts produced in cultures. Within the first month after isolation, all strains (with 1 exception, see 'Results') were checked at 1 to $3 \mathrm{~d}$ intervals for newly formed cysts. Older strains were controlled less frequently. Batches of new cysts were harvested by decanting the entire culture fluid together with the motile ciliates into a fresh culture dish. The original dish, with the cysts attached to its bottom, was refilled with sterile-filtered lake water and stored at cold/dark conditions. On May 7, a mixture of 7 batches of cysts produced by 6 different strains between March 6 and May 2 was fixed with $2 \%$ glutaraldehyde and critical point dried for examination by scanning electron microscopy (SEM). 
Excystment experiments with batches of laboratory cysts (Expts 6 \& 7). A large batch of cysts, which had been produced in a single culture between March 27 and April 6, 2001, was used for Expt 6. The cysts were harvested on April 6, filled into a culture bottle containing $80 \mathrm{ml}$ of sterile filtered lake water and stored over $5 \mathrm{mo}$ at cold/dark conditions. At 2 to $4 \mathrm{wk}$ intervals, 3 to $4 \mathrm{ml}$ subsamples were withdrawn after thorough mixing, without exposing the original sample to warm temperatures or light. Of these subsamples, $2 \mathrm{ml}$ were fixed and used to count intact, defect and open cysts in Sedgewick-Rafter chambers. Total numbers of cysts counted in each sample were 170 to 230 . The rest of the subsample was filled into a culture dish which contained $10 \mathrm{ml}$ of sterile filtered lake water and food algae, and was incubated under warm/light conditions (18 to $20^{\circ} \mathrm{C}$, see below). After $3 \mathrm{~d}$, the content of these dishes was fixed and the percentages of intact, defect and open cysts were determined as described above.

Seven batches of cysts produced between March 5 and June 3, were used for Expt 7. They were stored under cold/dark conditions until August 4 and then fixed the same day with acid Lugol's solution. Subsequently, the ratio of intact:defect:open cysts was determined by counting 300 to 600 cysts per sample.

Ranges of storage and incubation temperatures. Household refrigerators were used for storage under cold/dark conditions. In November 2000 and March 2001, the sediment samples had to be transferred to a different laboratory in thermo-boxes on ice. Therefore, storage temperature under cold/dark conditions showed some variation. From November through February, Sediment Samples 51 to 53 experienced temperatures from 1 to $4^{\circ} \mathrm{C}$, whereas Sample 51 was stored at 3 to $6^{\circ} \mathrm{C}$ in March/April. Storage temperature of laboratory cysts from March through August ranged from 3 to $7^{\circ} \mathrm{C}$. Incubation under warm conditions (with or without light) was done in a basement without temper- ature regulation. Temperatures in this room were 16 to $18^{\circ} \mathrm{C}$ during Expts 1 to 5 (January to April) and 18 to $20^{\circ} \mathrm{C}$ during Expt 6 (April to August).

\section{RESULTS}

\section{Fate of cysts in sediment samples}

The decline of strombidiid cysts with time in the sediment samples is illustrated in Fig. 1. Initial concentrations determined in November 2000 were 75, 79 and 71 cysts $\mathrm{ml}^{-1}$ in Samples 51, 52 and 53, respectively; these values were defined as $100 \%$. Only intact cysts (Fig. 2) were observed in these counts. On January 7 , numbers of intact cysts had decreased dramatically in Samples 52 and 53 . Only $2 \%$ of initial numbers were recorded in Sample 53, and no intact cysts could be detected in Sample 52. Instead, defect cysts (Fig. 3) were found, which had partly or totally lost their cell content, although plug and cyst wall appeared undamaged. These defect cysts accounted for ca. $50 \%$ of initial cyst concentrations; the fate of the rest of the cysts is unknown. Since it could be shown that the defect cysts were dead cysts (see Expt 1), Samples 52 and 53 were not studied any further.

In contrast, cyst concentrations in Sample 51 declined only slightly in January and February. On February 17, numbers of intact and defect cysts were 87 and $1 \%$ of initial numbers, respectively. Unfortunately, in order to save material, no subsample was taken during the next $6 \mathrm{wk}$. On March 30, 18\% of initial cyst numbers were open cysts without a plug (Fig. 4). A few active strombidiids were also recorded on this occasion, which confirmed that excystment had occurred under cold/dark conditions between February 17 and March 30, in Sample 51. On April 30, open cysts had increased to $44 \%$ and intact cysts had decreased to $4 \%$ of initial numbers.
Fig. 1. Percentages of intact, defect and open cysts in Sediment Samples 51 to 53 from Lake Mondsee during storage under cold/dark conditions from November 2000 through April 2001. Initial cyst concentrations in November were defined as $100 \%$. Numbers above columns signify the mean age (d) of the cysts (range: $\pm 3 \mathrm{~d}$ )

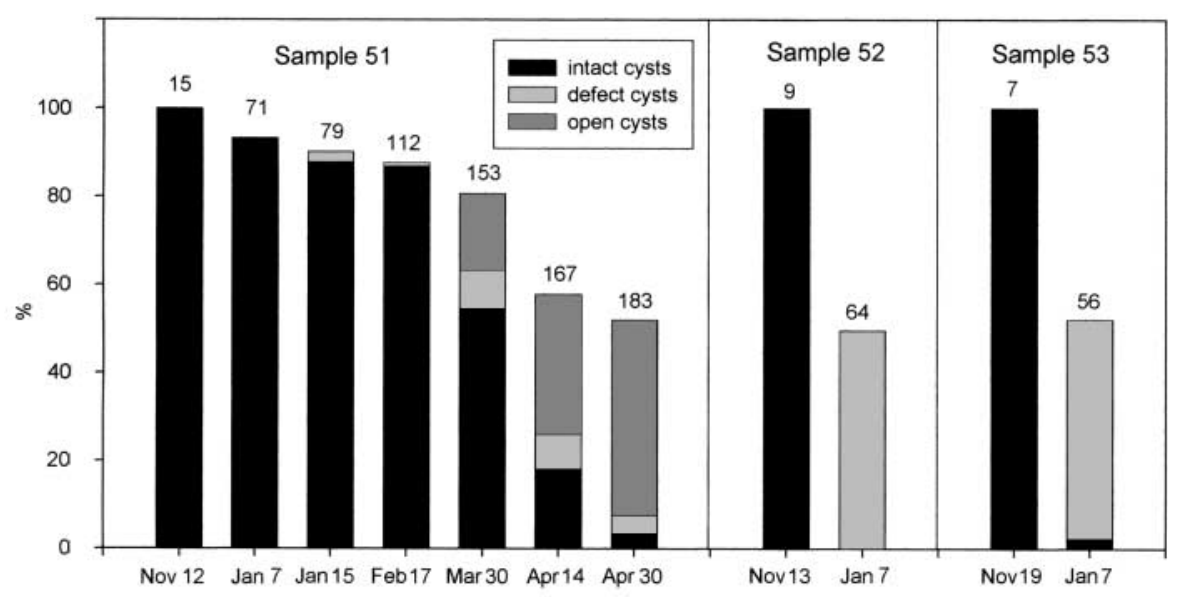



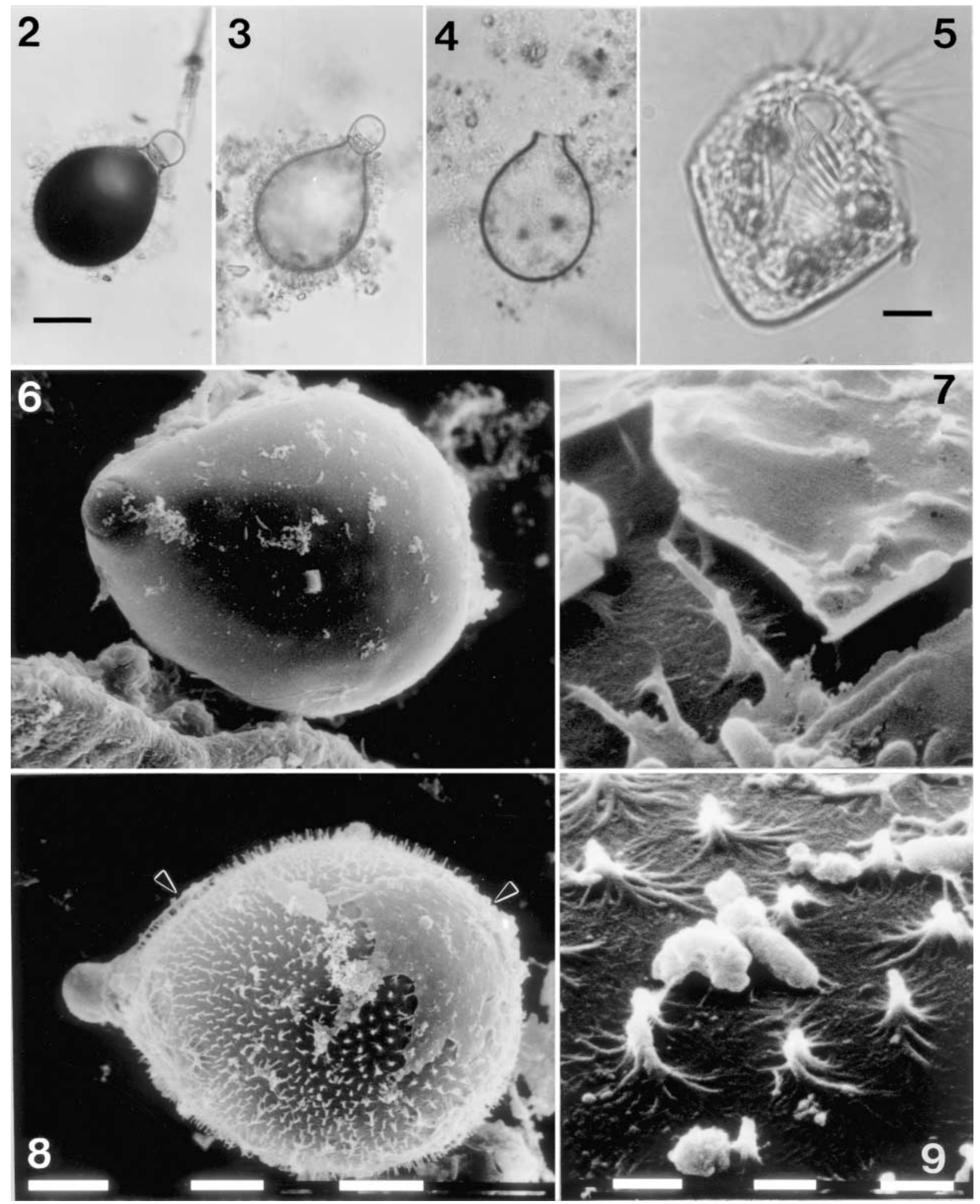

Figs. 2 to 4. Intact, defect and open cysts from Sediment Sample 51 collected in Lake Mondsee. Lugol-fixation. Scale bar $=20 \mu \mathrm{m}$. Fig. 5. Live cultured specimen of Pelagostrombidium, a descendant from excysted individuals of Expt 1 . Scale bar $=10 \mu \mathrm{m}$. Figs. 6 to 9. SEM graphs of laboratory cysts. Fig. 6. Pelagostrombidium cyst wrapped in 'envelope'. Fig. 7. Details of cyst with

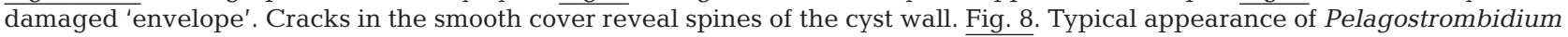
cyst with spines on its surface. Arrows point to rests of the 'envelope'. Fig. 9. Cyst surface with spines. Figs. 6 \& 8. Scale bar $=$ $10 \mu \mathrm{m}$. Figs. $7 \&$ 9. Scale $\overline{\mathrm{bar}=1} \mu \mathrm{m}$ 


\section{Induced excystment from sediment samples (Expts 1 to 5)}

Expt 1 was started on January 7, when cyst concentrations were 70 intact cysts $\mathrm{ml}^{-1}$ in Sample 51, 39 defect cysts $\mathrm{ml}^{-1}$ in Sample 52, and 35 defect cysts and 2 intact cysts $\mathrm{ml}^{-1}$ in Sample 53. By inoculation of $60 \mu \mathrm{l}$ of sediment sample, therefore, on average 4 intact cysts (Sample 51) or 2 defect cysts (Samples 52 and 53) were added to each well of the tissue culture plates.

Active strombidiids appeared after $1 \mathrm{~d}$ of incubation under warm/light conditions in 12 wells of the plate, which had been inoculated with Sample 51. After $3 \mathrm{~d}$ of incubation, active strombidiids were present in 19 of the 24 wells of the plate; during the following $2 \mathrm{~d}$, there was no evidence for further excystment. By live observation, excysted ciliates were identified to the genus Pelagostrombidium (Fig. 5). Additionally, copepod nauplii appeared in 2 wells, while in 1 well, a population of the ciliate Strobilidium lacustris developed.

In the plates which had been inoculated with Samples 52 and 53, no active strombidiids were observed during $5 \mathrm{~d}$ of incubation under warm/light conditions. Only a few copepod nauplii and rotifers appeared in these plates. No protozoans or metazoans showed up in the control plate.

Results of Expts 2, 3, 4 \& 5 with Sediment Sample 51 are summarized in Table 1 . Under warm/light conditions, excystment started after $1 \mathrm{~d}$ ( $2 \mathrm{~d}$ in Expt 3 ) of incubation. After $3 \mathrm{~d}$, excysted ciliates were present in 14 to 15 of 24 wells. Only a few additional wells with active ciliates were recorded during the following 2 to 4 d. The plates incubated under warm/dark and cold/dark conditions were checked less frequently to minimize exposure to warm temperature and light.

Comparison of the results obtained under warm/ light and warm/dark conditions does not give a clear picture of the impact of light on excystment. Light apparently had a positive effect in Expt 3, but not in Expt 4, while in Expts 2 \& 5, the excystment response was delayed under dark conditions. However, since dark plates were exposed to light for ca. 30 min during observation, excystment after $3 \mathrm{~d}$ could have been stimulated by this short period of illumination.

Comparison of the results obtained at warm/dark and cold/dark conditions reveals the strong impact of temperature. At cold/dark conditions, excystment was never recorded in Expts 2 \& 3 and very rarely in Expts $4 \& 5$. Notably, the latter experiments were performed at a time when spontaneous excystment had already started (cf. Fig. 1).

\section{Cyst formation in culture}

All 12 strains which had been established from excysted individuals produced cysts in culture (Table 2). Cyst formation started 2 to $3 \mathrm{wk}$ after excystment. In all strains, only a fraction of the population encysted and the remaining active ciliates continued to produce batches of cysts for several weeks. Cultures were discontinued when they showed signs of senescence, such as very slow growth and incomplete divisions. Conjugation was never observed.

SEM micrographs of laboratory cysts are presented in Figs. 6 to 9. Surprisingly, 2 types of cyst wall structure were observed. While most specimens were covered with spines (Figs. 8 \& 9), a typical feature of Pelagostrombidium cysts according to Müller (1996), some seemed to have a smooth surface (Fig. 6). However, a closer look (Fig. 7) revealed that these specimens also had spines, which were hidden under a smooth cover. Presumably, all cysts are first produced within such an 'envelope', which disintegrates with time.

\section{Spontaneous and induced excystment in a single batch of laboratory cysts (Expt 6)}

Expt 6 was designed to study induced and spontaneous excystment relative to cyst age. A large batch of

Table 1. Numbers of wells with active Pelagostrombidium in 24 well tissue culture plates incubated under warm/light, warm/dark and cold/dark conditions. -: no data

\begin{tabular}{|c|c|c|c|c|c|c|c|c|c|c|c|c|}
\hline \multirow{2}{*}{$\begin{array}{l}\text { Days of } \\
\text { incubation }\end{array}$} & \multicolumn{3}{|c|}{- Expt $2(\operatorname{Jan} 15)-$} & \multicolumn{3}{|c|}{- Expt 3 (Feb 18) } & \multicolumn{3}{|c|}{ — Expt 4 (Mar 31) } & \multicolumn{3}{|c|}{- Expt 5 (Apr 15) — } \\
\hline & $\begin{array}{c}\text { Warm/ } \\
\text { light }\end{array}$ & $\begin{array}{l}\text { Warm/ } \\
\text { dark }\end{array}$ & $\begin{array}{l}\text { Cold/ } \\
\text { dark }\end{array}$ & $\begin{array}{c}\text { Warm/ } \\
\text { light }\end{array}$ & $\begin{array}{l}\text { Warm/ } \\
\text { dark }\end{array}$ & $\begin{array}{l}\text { Cold/ } \\
\text { dark }\end{array}$ & $\begin{array}{c}\text { Warm/ } \\
\text { light }\end{array}$ & $\begin{array}{l}\text { Warm/ } \\
\text { dark }\end{array}$ & $\begin{array}{l}\text { Cold/ } \\
\text { dark }\end{array}$ & $\begin{array}{c}\text { Warm/ } \\
\text { light }\end{array}$ & $\begin{array}{l}\text { Warm/ } \\
\text { dark }\end{array}$ & $\begin{array}{l}\text { Cold/ } \\
\text { dark }\end{array}$ \\
\hline 1 & 4 & - & - & 0 & - & - & 10 & - & - & 11 & - & - \\
\hline 2 & 14 & - & - & 15 & - & - & 13 & - & - & 14 & - & - \\
\hline 3 & 14 & 8 & 0 & 15 & - & - & 15 & 15 & 0 & 15 & 8 & 1 \\
\hline 4 & - & - & - & 18 & 7 & 0 & 15 & - & - & - & - & - \\
\hline 5 & 17 & 18 & 0 & - & - & - & 15 & 15 & 1 & 16 & 15 & 2 \\
\hline 7 & - & - & - & 18 & 8 & 0 & - & - & - & - & - & - \\
\hline
\end{tabular}


Table 2. Time table of 12 Pelagostrombidium strains (from October 2000 to August 2001) originating from excysted ciliates in Expts 1, 3, 4 \& 5. Strain 1.1 was not examined between January 20 and March 6; the date of its first cyst production, therefore, is unknown. Strains $3.1 \& 3.2,3.3 \& 3.4$ and $3.5 \& 3.6$ are pairs of parallel strains. ${ }^{*}=$ cyst batches used in Expt $7,{ }^{* *}=$ cyst batch $^{*}$ used in Expt 6. nd = not determined

\begin{tabular}{|c|c|c|c|c|c|c|}
\hline $\begin{array}{l}\text { Formation of } \\
\text { field cysts }\end{array}$ & $\begin{array}{c}\text { Strain } \\
\text { no. }\end{array}$ & $\begin{array}{l}\text { Excystment and } \\
\text { start of culture }\end{array}$ & $\begin{array}{c}\text { First record of } \\
\text { new cysts }\end{array}$ & $\begin{array}{c}\text { Time between } \\
\text { excystment and } \\
\text { encystment (wk) }\end{array}$ & $\begin{array}{l}\text { Harvest of } \\
\text { cyst batches }\end{array}$ & $\begin{array}{l}\text { End of } \\
\text { culture }\end{array}$ \\
\hline October & 1.1 & Jan 8-9 & nd & nd & Mar 21-24*/Mar 24-Apr 6 & May 12 \\
\hline \multirow{11}{*}{$25-31$} & 3.1 & Feb $20-21$ & Mar 6 & 2 & Mar 5-6*/Mar 6-7/Mar 7-9*/Mar 27-Apr 6** & Jun 3 \\
\hline & 3.2 & Feb $20-21$ & Mar 15 & 3 & Mar 15-18/Mar 20-Apr 6 & Apr 6 \\
\hline & 3.3 & Feb $20-21$ & Mar 15 & 3 & Mar 15-18*/Mar 18-21 & May 2 \\
\hline & 3.4 & Feb $20-21$ & Mar 15 & 3 & Mar $15-18$ & Apr 6 \\
\hline & 3.5 & Feb $20-21$ & Mar 16 & 3 & Mar 16-18 & Mar 18 \\
\hline & 3.6 & Feb $20-21$ & Mar 15 & 3 & & Mar 18 \\
\hline & 4.1 & Apr 1-3 & Apr 20 & 2.5 & Apr $26-29^{*} /$ May $3-12^{*}$ & Jun 3 \\
\hline & 4.4 & Apr 1-3 & Apr 23 & 3 & & May 2 \\
\hline & 4.5 & Apr 1-3 & Apr 23 & 3 & Apr 23-May 2 & Jun 3 \\
\hline & 5.1 & Apr 16-18 & May 6 & 3 & & Aug 5 \\
\hline & 5.2 & Apr 16-18 & May 6 & 3 & May 20-Jun $3^{*}$ & Aug 5 \\
\hline
\end{tabular}

ca. 8000 cysts was used, which had been produced within a period of $10 \mathrm{~d}$ by Strain 3.1 (cf. Table 2). Total cyst concentrations in this sample (ca. 100 cysts $\mathrm{ml}^{-1}$ ) were stable throughout the experimental time of ca. $4 \mathrm{mo}$. The share of defect cysts increased from 1 to $28 \%$ over this period.

Percentages of open cysts recorded throughout the experiment are shown in Fig. 10. Excystment at cold/dark conditions was first observed in cysts older than $3 \mathrm{mo}$, when the share of open cysts increased from $0.5 \%$ at $110 \mathrm{~d}$ to $17 \%$ at $145 \mathrm{~d}$. A temperature shift from ca. 4 to $18^{\circ} \mathrm{C}$ had no effect in $30 \mathrm{~d}$ old cysts. Between 44 and $88 \mathrm{~d}$, the response to this shift increased significantly from 4 to $24 \%$ of open cysts, the

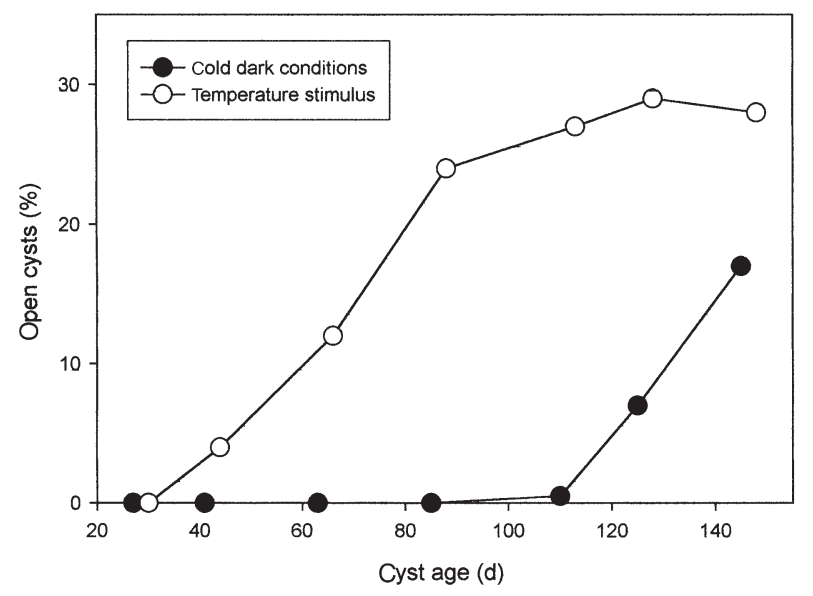

Fig. 10. Excystment in a single batch of cysts relative to cyst age and temperature (Expt 6). (•) Percentage of open cysts under cold/dark conditions; ( $(0)$ Percentage of open cysts $3 \mathrm{~d}$ after a rise in temperature from ca. 4 to $18^{\circ} \mathrm{C}$. Mean values of cyst age (d) are shown on the $x$-axis (range: $\pm 5 \mathrm{~d}$ ) highest value of $29 \%$ was reached when the cysts were ca. 4 mo old. The strong impact of cyst age on excystment under cold/dark and warm/light conditions is evident from these data.

\section{Spontaneous excystment in different batches of laboratory cysts (Expt 7)}

Expt 7 served to compare spontaneous excystment in 7 cyst batches from 5 strains, which had been produced between March 5 and June 3 (cf. Table 2), stored under cold/dark conditions and fixed simultaneously on August 4, 2001. Their ratios of intact:defect:open cysts on this date are shown in Fig. 11. In the 2 youngest batches, aged 62 to $76 \mathrm{~d}$, and 84 to $93 \mathrm{~d}$, the shares of open cysts were 0 and $1 \%$, respectively. These data agree with the observations in Expt 6, that spontaneous excystment starts at an age of ca. 3 mo. In the older batches, no relationship between cyst age and excystment could be detected. The percentage of open cysts did not exceed $22 \%$, except for 1 high value of $65 \%$. Likewise, the percentage of defect cysts in the older batches was not related to cyst age. This experiment, therefore, reveals individual differences between batches with respect to cyst health and readiness to excyst.

\section{DISCUSSION}

In the present investigation, a complete polymorphic cycle of the freshwater ciliate Pelagostrombidium sp. was followed under laboratory conditions, which comprised the phases of excystment, vegetative growth, encystment, dormancy and next excystment. However, 
not all facets of the life history of this strombidiid ciliate were covered, since conjugation, observed in the same species by Müller (1996), did not occur throughout the present study.

Experiments were designed to simulate environmental conditions which the cysts might experience in the lake of their origin, with the intention to use laboratory data for a better understanding of the life history of Pelagostrombidium sp. in temperate lakes. It should be considered, however, that only crude imitations of the field conditions were achieved.

\section{Losses of cysts in the sediment}

The data presented in Fig. 1 show a great vulnerability of the Pelagostrombidium cysts. Storage temperature during the first $3 \mathrm{mo}$, when dramatic losses occurred in Sediment Samples 52 and 53, did not exceed $4{ }^{\circ} \mathrm{C}$ and thus, was comparable to temperatures at the lake bottom.

In contrast to the field conditions, the samples were not subjected to water movements and no new sediment layers were added. This could have positively or negatively affected the development of presumptive predators and parasites.

It is unknown which organisms preyed upon the cysts in these samples. Large metazoans had been removed by sieving through $200 \mu \mathrm{m}$ mesh. Presumptive predators in the fractions $<200 \mu \mathrm{m}$ were benthic ciliates (e.g. Spirostomum), nematodes and small crustaceans such as chydorids. These organisms showed up only occasionally and were not quantified: there were, however, no obvious differences in their abundance which could have explained the much higher losses of cysts in Samples 52 and 53. The processes leading to defect cysts are also enigmatic. Parasitic microorganisms might be able to invade the cells through lesions in the cyst wall. Although the present data do not serve to quantify predation and infection, they suggest that losses of cysts by these processes can be significant.

\section{Spontaneous excystment}

Excystment under cold/dark conditions of $>3$ mo old cysts was recorded in 3 independent experiments with field and laboratory cysts (Figs. 1, 10 \& 11). Although there was no obvious external trigger, it cannot be excluded that small variations in storage temperature (see 'Methods') could have promoted excystment. However, cysts in sediments of deep lakes also experience small variations in temperature. At the sampling

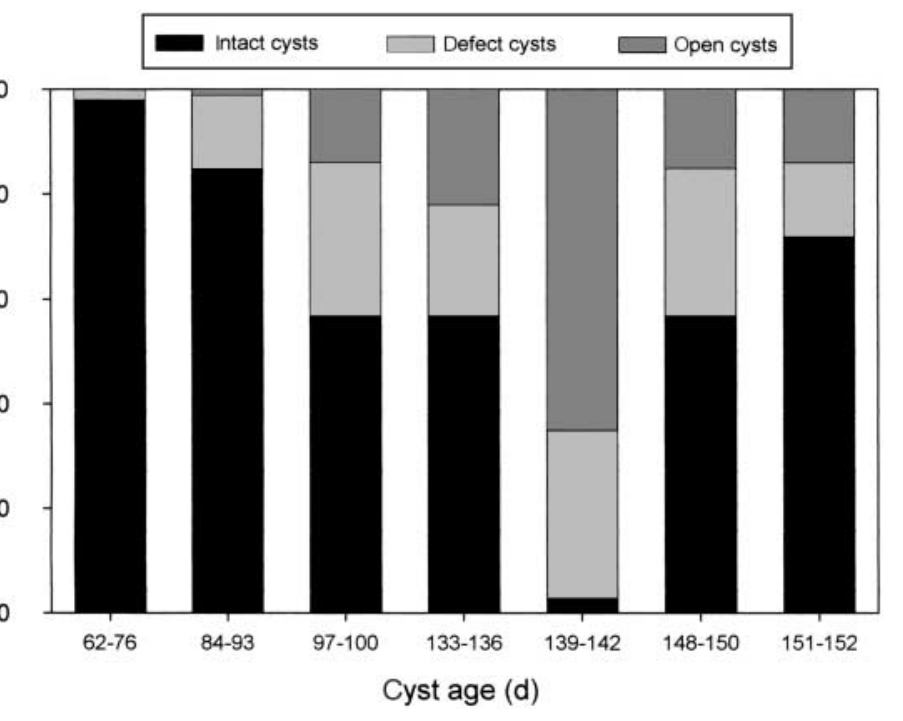

Fig. 11. Percentages of intact, defect and open cysts in 7 batches of cysts from 5 strains (cf. Table 2) relative to cyst age (Expt 7 )

location in Lake Mondsee, where the original sediment samples had been collected at $45 \mathrm{~m}$ depth, water temperatures at $40 \mathrm{~m}$ depth were measured weekly and ranged from 2.9 to $6.0^{\circ} \mathrm{C}$ over the annual cycle in 2000 , with the lowest and highest values recorded in February and September, respectively. From November 2000 through March 2001, the storage period of Sample 51 in the laboratory, water temperatures in the lake at $40 \mathrm{~m}$ depth varied between 3.7 and $5.7^{\circ} \mathrm{C}(\mathrm{H}$. Müller, P. Stadler \& T. Weisse unpubl. data).

Nevertheless, the decisive parameter controlling excystment at cold/dark conditions obviously was cyst age. Open cysts were first found ca. 3 mo after encystment (Figs. 1, $10 \& 11$ ). Within the same batch, their share gradually increased during the following 2 to 3 mo (Figs. 1 \& 10). These data indicate that Pelagostrombidium cysts deposited in sediments of deep lakes in late autumn should be able to excyst in early spring without an external trigger.

Excystment of oligotrich ciliates at cold/dark conditions has not been reported to date. Paranjape (1980) observed spontaneous excystment of the marine tintinnid Helicostomella subulata under simulated 'summer conditions' of 12 to $14^{\circ} \mathrm{C}$ and a $14: 10 \mathrm{~h}$ light:dark cycle. Under simulated 'winter conditions' $\left(4^{\circ} \mathrm{C}\right.$, darkness), these cysts remained dormant for $7 \mathrm{mo}$.

Resting stages of planktonic metazoans are known to survive for decades in the sediment of lakes; thus, forming egg banks which serve as biotic reservoirs (Hairston 1996 and references therein). In contrast, the present data suggest that the period of dormancy of Pelagostrombidium cysts generally does not exceed 6 mo, a hypothesis which needs to be tested by exam- 
ining sediment samples from deeper strata for the resting stages of this strombidiid ciliate.

\section{External factors controlling excystment}

Temperature has been identified as the principal external factor triggering excystment in marine tintinnids (Paranjape 1980, Kamiyama \& Aizawa 1990, 1992) and the aloricate oligotrich Strombidium conicum (Kim \& Taniguchi 1995, 1997). The results of the present investigation agree with these findings. They also demonstrate a significant relationship between the temperature response of Pelagostrombidium sp. and cyst age (Fig. 10). Due to limitations in equipment, no optimum or threshold temperatures were determined.

Under natural conditions, only those resting stages which are deposited in shallow regions of oceans and lakes will be exposed to significant changes in ambient temperature. Kim \& Taniguchi (1997), who studied a population of Strombidium conicum in Onagawa Bay, Japan, reported a significant relationship between the seasonal excystment pattern and mud temperature, which at the study site (at $22 \mathrm{~m}$ depth) varied seasonally between 8 and $18^{\circ} \mathrm{C}$.

Other external factors reported to enhance the excystment response of marine oligotrich ciliates are light (Paranjape 1980, Kamiyama et al. 1995, Kim \& Taniguchi 1995), presence of food algae or their extracellular products (Kamiyama 1994, 1997), presence of bacteria and high oxygen levels (Kim \& Taniguchi 1995). The present study provides limited information on the impact of light and food algae (Table 1). In 3 of 4 experiments, white light enhanced or accelerated the excystment response, which however was also strong in the dark. Since all experiments were performed in the presence of cryptomonads, these could have also enhanced the excystment response. As a single factor under cold/dark conditions, cryptomonads obviously did not trigger excystment. The few active ciliates recorded under cold/dark conditions in Expts 4 \& 5 (Table 1) most probably emerged spontaneously, since the cysts in these experiments were older than 3 mo.

\section{Encystment in culture}

Cyst formation in freshly established cultures, only 2 to 3 wk after excystment, was an unexpected result. Since conjugation was never observed, it obviously is not an essential step between excystment and encystment.

All strains were started with food in excess; new cryptomonads were added when they had been grazed down. Although changing food concentrations were not systematically determined in these rapidly growing batch cultures, the encystment pattern appeared to be the same as described by Müller (1996) in batch cultures of Pelagostrombidium from Lake Constance: cyst formation started at high algal concentrations and was enhanced when the food was depleted.

Encystment in cultures devoid of potential predators (Müller 1996, this study) shows that their presence is not essential for the encystment response. This agrees with observations by Müller \& Wünsch (1999), who during their field study in Lake Constance, did not find a significant relationship between flux rates of strombidiid cysts and abundance of crustaceans. According to our present knowledge, therefore, strombidiid encystment most probably is not triggered by predator kairomones. Nonetheless, encystment during phytoplankton blooms could be an efficient predator avoidance strategy, as discussed by Reid (1987) and Müller et al. (2002), due to the time delay between ciliate population growth with subsequent cyst production and mass development of their metazoan predators.

Notably, all strains derived from excysted individuals readily formed cysts, whereas in my experience, cyst forming strains are only exceptionally obtained by isolation of planktonic specimens from lake water. This points to a genetic variability within the population, creating variable responses to external triggers for encystment. This hypothesis agrees with observations by Müller et al. (2002), that some individuals of the Pelagostrombidium population in Lake Mondsee encyst in late autumn, whereas others stay active throughout the winter months. Coexistence of these contrasting strategies may be explained by the variability of external factors which control survival rates of active and encysted specimens during winter, such as weather conditions (strong or mild winter), food supply and predation pressure in the water column, and predation on cysts in the sediment.

\section{Life cycle}

The present data were combined with observations from previous field studies in Lake Constance (Müller \& Wünsch 1999) and Lake Mondsee (Müller et al. 2002) to give the following tentative description of the polymorphic cycle of Pelagostrombidium sp. in temperate lakes.

Autumn cysts are formed at the end of the growing season (Müller \& Wünsch 1999, Müller et al. 2002). These will excyst spontaneously in early spring (February/March) under cold/dark conditions after 4 to 5 mo of dormancy (Fig. 1). Excystment in nearshore areas may be promoted by light and elevated temperatures (Expts 1 to 5, Table 1). Since at this time of the year the 
lakes are not stratified, the ciliates emerging at greater depth may reach the lake surface by water movements.

Populations descending from excysted individuals are able to encyst after a few weeks of vegetative growth (Table 2). Therefore, ciliates excysting in March may form new cysts in April/May. The respective data from the 2 field studies are inconsistent. Cyst production in Lake Mondsee was negligible in spring, although well-fed laboratory cultures descending from the Lake Mondsee population produced large numbers of cysts at the same time (Table 2). In contrast, a prominent maximum of spring cysts was recorded in Lake Constance. This suggests that a period of high food availability is a prerequisite for cyst production in spring. The rapid growth response of the ciliate community, including the strombidiids, to the phytoplankton bloom in Lake Constance is well documented (Weisse et al. 1990, Müller et al. 1991, Müller \& Wünsch 1999), whereas the ciliates in Lake Mondsee for unknown reasons were not able to exploit the phytoplankton maximum in April (Müller et al. 2002).

Spring cysts deposited in nearshore areas may excyst after 1 to 2 mo of dormancy, depending on ambient temperature. Those sinking to greater depth will excyst spontaneously under cold/dark conditions in August/September (Expt 6, Fig. 10). However, only ciliates emerging in more shallow regions will have a good chance of reaching surface waters during this time of lake stratification. After a few weeks or months of vegetative growth, the motile population will start to produce large numbers of autumn cysts. The nature of the environmental signal triggering and coordinating cyst formation in autumn remains unknown.

The scenario described so far is only concerned with those individuals which readily encyst. In parallel, there seems to be a fraction of the population which remains active throughout the year. The role of conjugation, which might serve as a link between these 2 subpopulations, needs to be investigated.

Acknowledgements. I wish to thank Peter Stadler (Institute for Limnology, Mondsee) for collecting the sediment samples from Mondsee and providing sterile-filtered lake water, Joachim Hentschel (University of Konstanz) for skilled performance of scanning electron microscopy, and Thomas Weisse (Mondsee) for critical comments on earlier versions of this text. Three anonymous referees offered constructive suggestions on the submitted manuscript.

\section{LITERATURE CITED}

Corliss JO, Esser SC (1974) Comments on the role of the cyst in the life cycle and survival of free-living protozoa. Trans Am Microsc Soc 93:578-593

Fauré-Fremiet E (1948) Le rythme de marée du Strombidium oculatum Gruber. Bull Biol France Belg 82:3-23
Foissner W, Berger H, Schaumburg J (1999) Identification and ecology of limnetic planktonic ciliates. Informationsberichte des Bayer Landesamtes für Wasserwirtschaft, Munich, Heft 3/99

Gutiérrez JC, Martin-González A, Callejas S (1998) Nuclear changes, macronuclear chromatin reorganization and DNA modification during ciliate encystment. Europ J Protistol 34:97-103

Gutiérrez JC, Callejas S, Borniquel S, Benitez L, MartinGonzález A (2001) Ciliate cryptobiosis: a microbial strategy against environmental starvation. Int Microbiol 4: 151-157

Hairston NG Jr (1996) Zooplankton egg banks as biotic reservoirs in changing environments. Limnol Oceanogr 41: $1087-1092$

Jonsson PR (1994) Tidal rythm of cyst formation in the rock pool ciliate Strombidium oculatum Gruber (Ciliophora, Oligotrichida): a description of the functional biology and an analysis of the tidal synchronization of encystment. J Exp Mar Biol Ecol 175:77-103

Kamiyama T (1994) Effects of extracellular products from phytoplankton on the excystment of tintinnids from marine sediments. Mar Ecol Prog Ser 105:199-201

Kamiyama T (1997) Effects of phytoplankton abundance on excystment of tintinnid ciliates from marine sediments. J Oceanogr 53:299-302

Kamiyama T, Aizawa Y (1990) Excystment of tintinnid ciliates from marine sediments. Bull Plankton Soc Japan 36: $137-139$

Kamiyama T, Aizawa Y (1992) Effects of temperature and light on tintinnid excystment from marine sediments. Nippon Suisan Gakkaishi 58:877-884

Kamiyama, Itakura S, Nagasaki K (1995) Effects of irradiance on excystment of tintinnids from marine sediments. J Oceanogr 51:615-618

Kim YO, Taniguchi A (1995) Excystment of the oligotrich ciliate Strombidium conicum. Aquat Microb Ecol 9:149-156

Kim YO, Taniguchi A (1997): Seasonal variation of excystment pattern of the planktonic oligotrich ciliate Strombidium conicum. Mar Biol 128:207-212

Montagnes DJS, Wilson D, Brooks SJ, Lowe C, Campey M (2002) Cyclical behaviour of the tide-pool ciliate Strombidium oculatum. Aquat Microb Ecol 28:55-68

Müller H (1996) Encystment of the freshwater ciliate Pelagostrombidium fallax (Ciliophora, Oligotrichida) in laboratory culture. Aquat Microb Ecol 11:289-295

Müller H (2000) Evidence of dormancy in planktonic oligotrich ciliates. Verh Internat Verein Limnol 27:3206-3209

Müller H, Wünsch C (1999) Seasonal dynamics of cyst formation of pelagic strombidiid ciliates in a deep prealpine lake. Aquat Microb Ecol 17:37-47

Müller H, Schöne A, Pinto-Coelho RM, Schweizer A, Weisse $T$ (1991) Seasonal succession of ciliates in Lake Constance. Microb Ecol 21:119-138

Müller H, Stadler P, Weisse T (2002) Seasonal dynamics of cyst formation of strombidiid ciliates in alpine Lake Mondsee, Austria. Aquat Microb Ecol 29:181-188

Paranjape MA (1980) Occurrence and significance of resting cysts in a hyaline tintinnid, Helicostomella subulata (Ehre) Jorgensen. J Exp Mar Biol Ecol 48:23-33

Reid PC (1987) Mass encystment of a planktonic oligotrich ciliate. Mar Biol 95:221-230

Weisse T, Müller H, Pinto-Coelho R, Schweizer A, Springmann D, Baldringer G (1990) Response of the microbial loop to the phytoplankton spring bloom in a large prealpine lake. Limnol Oceanogr 35:781-794

Submitted: February 11, 2002; Accepted: June 18, 2002

Proofs received from author(s): August 27, 2002
Editorial responsibility: Karel Šimek,

České Budějovice, Czech Republic 